\title{
Contents of Volume 105 (1990)
}

\section{Authors and Titles}

ANDREWS, WILliaM L. (Univ. of Kansas). The Novelization of Voice in Early African American Narrative ANY, CAROL (Trinity Coll., CT). Boris Eikhenbaum's Unfinished Work on Tolstoy: A Dialogue with Soviet

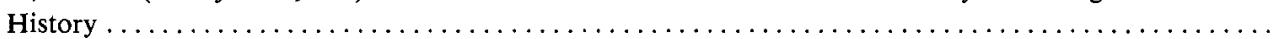
BENSTON, KIMBERLY W. (Haverford Coll.). Facing Tradition: Revisionary Scenes in African American

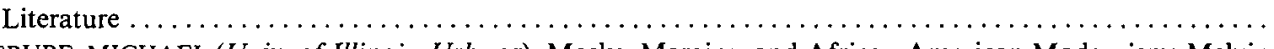
BERUBE, MICHAEL (Univ. of Illinois, Urbana). Masks, Margins, and African American Modernism: Melvin Tolson's Harlem Gallery.

BROMBERT, VICTOR (Princeton Univ.). Presidential Address 1989. Mediating the Work: Or, The Legitimate

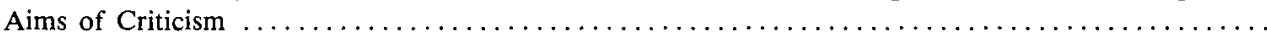

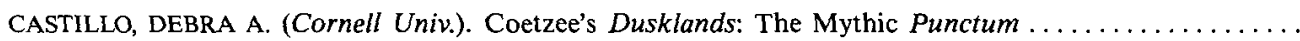
CUDDY-KEANE, MELBA (Univ. of Toronto, Scarborough Campus). The Politics of Comic Modes in Virginia

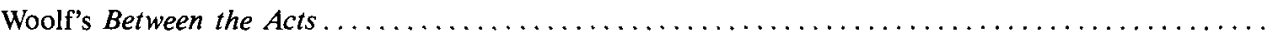
CUNNINGHAM, KAREN (Florida State Univ.). Renaissance Execution and Marlovian Elocution: The Drama

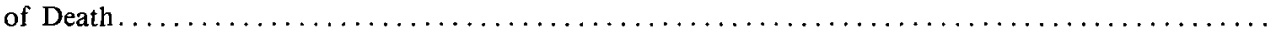
GALLOWAY, ANDREW (Univ. of California, Berkeley). Beowulf and the Varieties of Choice........... GATES, HENRY LOUIS, JR. (National Humanities Center). "Tell Me, Sir, . . . What Is 'Black' Literature?" GURALNICK, EliSSA S. (Univ. of Colorado, Boulder). Artist Descending a Staircase: Stoppard Captures the

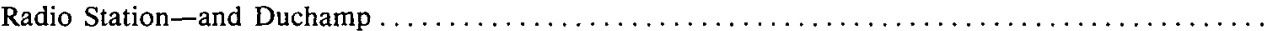
HENKEL, JACQUELINE (Univ. of Texas, Austin). Linguistic Models and Recent Criticism: Transformational-

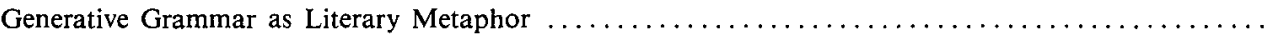
HILLIARD, RAYMOND F. (Univ. of Richmond). Clarissa and Ritual Cannibalism ................. HOSTETLER, ANN E. (Univ. of Pennsylvania). The Aesthetics of Race and Gender in Nella Larsen's Quicksand JACKSON, EARL, JR. (Univ. of California, Santa Cruz). The Metaphysics of Translation and the Origins of

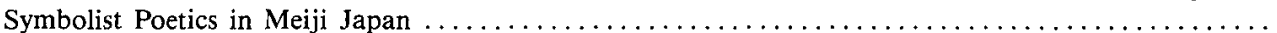
KAHN, VICTORIA (Princeton Univ.). Habermas, Machiavelli, and the Humanist Critique of Ideology ... KAUFMANN, DAvid (George Mason Univ.). The Profession of Theory $\ldots \ldots \ldots \ldots \ldots \ldots \ldots \ldots$ KAUL, SUVIR (S. G. T. B. Khalsa Coll., Univ. of Delhi). Why Selima Drowns: Thomas Gray and the Domes-

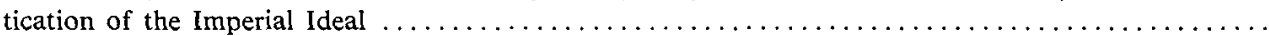
KOELB, CLAYTON (Univ. of Chicago). Incorporating the Text: Kleist's "Michael Kohlhaas" .......... KNOEPFLMACHER, U. C. (Princeton Univ.). Hardy Ruins: Female Spaces and Male Designs .......... LEINWAND, THEODORE B. (Univ. of Maryland, College Park). Negotiation and New Historicism ...... LEVIN, RICHARD (State Univ. of New York, Stony Brook). The Poetics and Politics of Bardicide ......

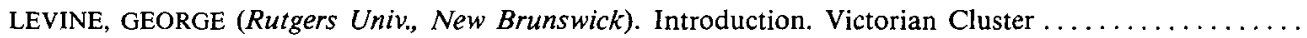
LINDENBERGER, HERBERT (Stanford Univ.). Ideology and Innocence: On the Politics of Critical Language MERMALL, THOMAS (Brooklyn Coll. and Graduate Center, City Univ. of New York). The Chiasmus:

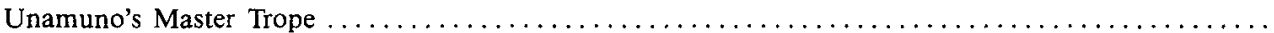
MILLER, ANDREW (Indiana Univ., Bloomington). Vanity Fair through Plate Glass.............. 
NEWMAN, BETH (Southern Methodist Univ.). "The Situation of the Looker-On": Gender, Narration, and Gaze

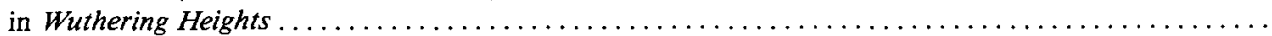
RAND, NICHOLAS (Univ. of Wisconsin, Madison). The Political Truth of Heidegger's "Logos": Hiding in

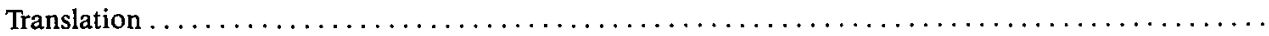
SOYINKA, WOLE (Abeokuta, Nigeria). Twice Bitten: The Fate of Africa's Culture Producers . . . ........ STAIGER, EMIL, MARTIN HEIDEGGER, AND LEO SPITZER. A 1951 Dialogue on Interpretation ........... VARGAS lloSA, MARIO (Lima, Peru). Updating Karl Popper. Suspect Truth; The Closed Society and the Third

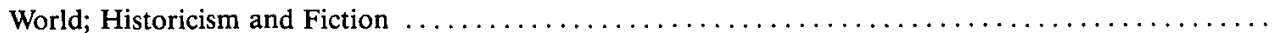

WARD, CYNTHIA (Stanford Univ.). What They Told Buchi Emecheta: Oral Subjectivity and the Joys of

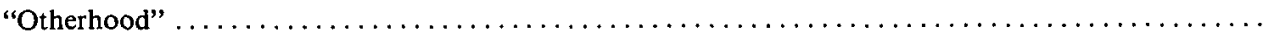
WINNETT, SUSAN (Columbia Univ.). Coming Unstrung: Women, Men, Narrative, and Principles of Pleasure

\section{Miscellaneous}

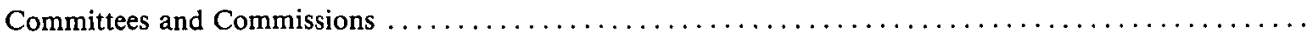

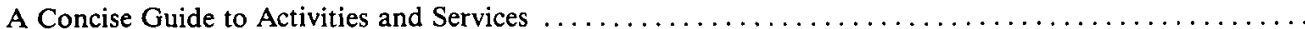

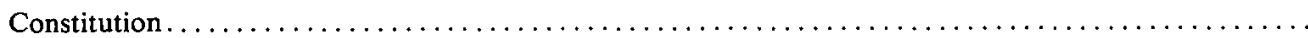

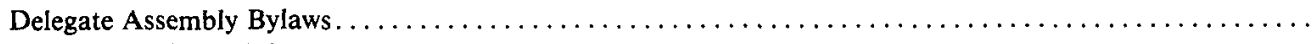

Departmental Administrators

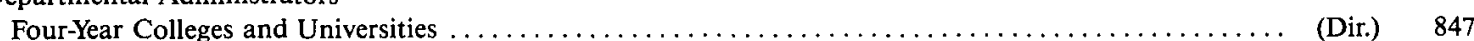

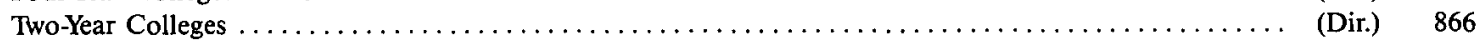

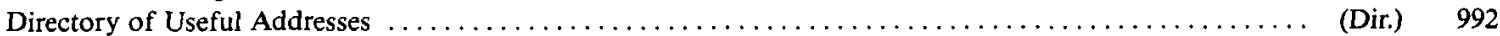

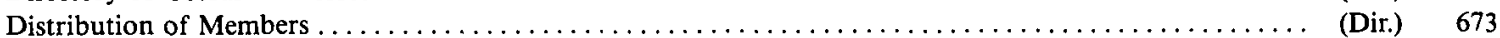

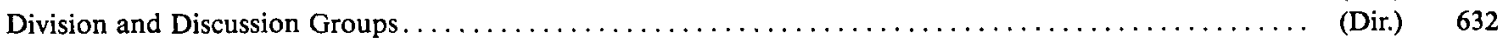

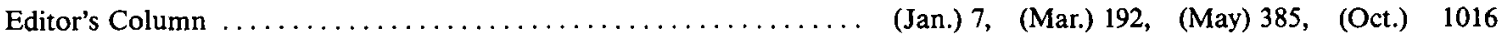

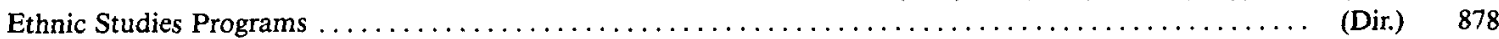

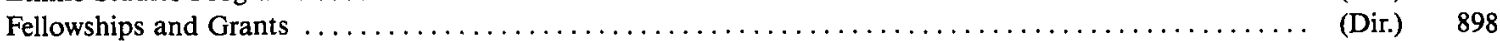

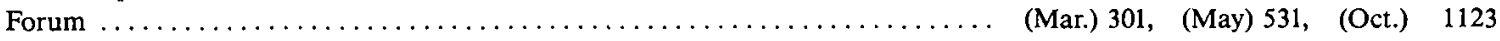

Governance Structure

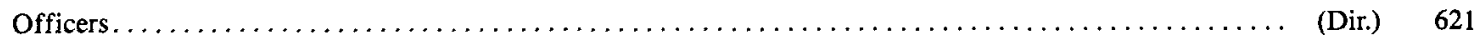

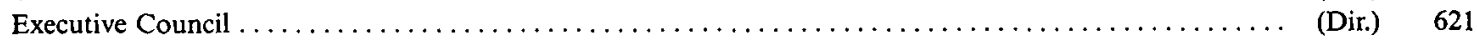

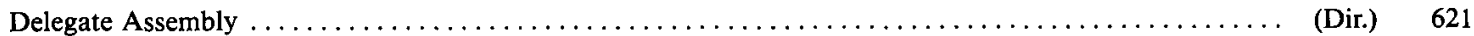

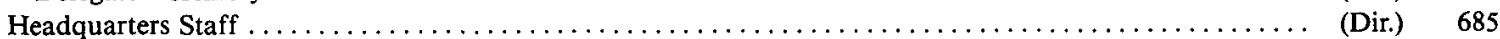

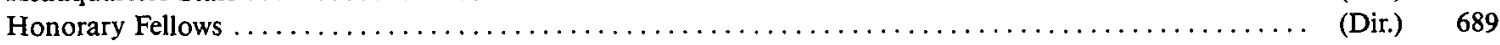

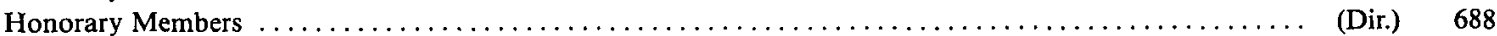

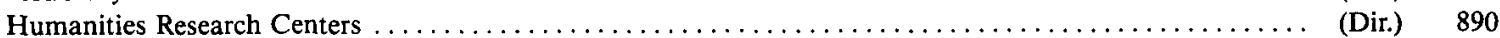

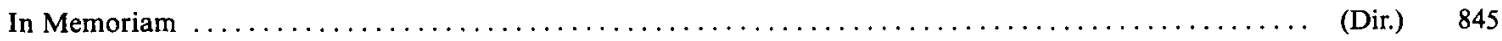

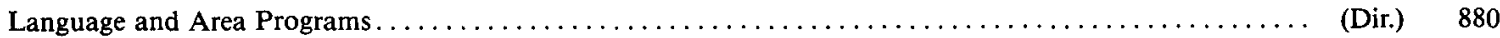

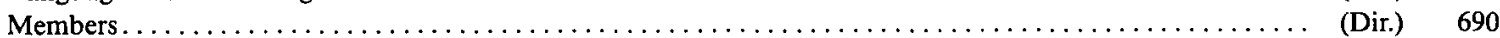

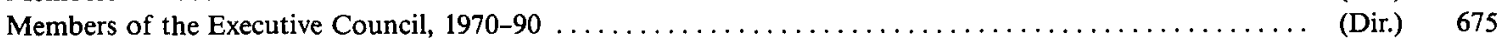

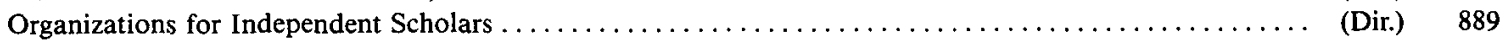

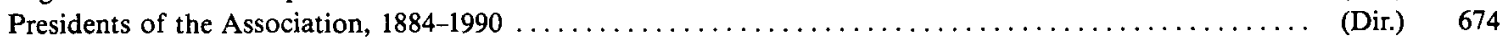

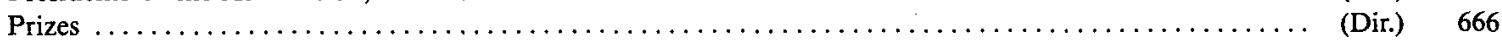

Procedures for Organizing Meetings for the Convention and Policies for Divisions and Discussion Groups. (Dir.) 641

Professional Notes and Comment.............. (Jan.) 138, (Mar.) 330, (May) 562, (Dir.) 936, (Oct.) 1168

Proposed Amendments to the Constitution $\ldots \ldots \ldots \ldots \ldots \ldots \ldots \ldots \ldots \ldots \ldots \ldots \ldots \ldots \ldots \ldots \ldots \ldots, \ldots \ldots$ (Dir.) $660 \ldots \ldots \ldots$

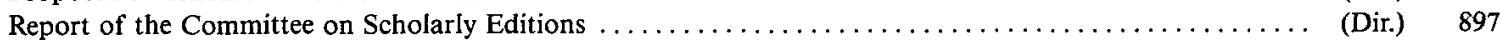

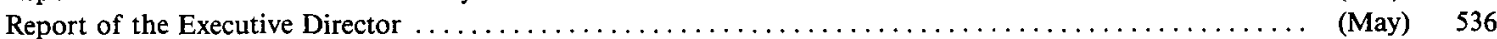

Reports of the Regional Modern Language Associations $\ldots \ldots \ldots \ldots \ldots \ldots \ldots \ldots \ldots \ldots \ldots \ldots \ldots \ldots \ldots$ (Dir.) 891

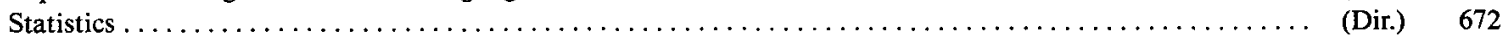

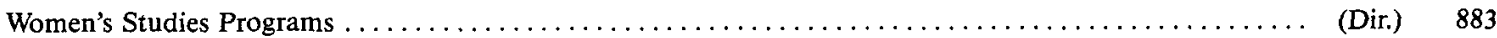




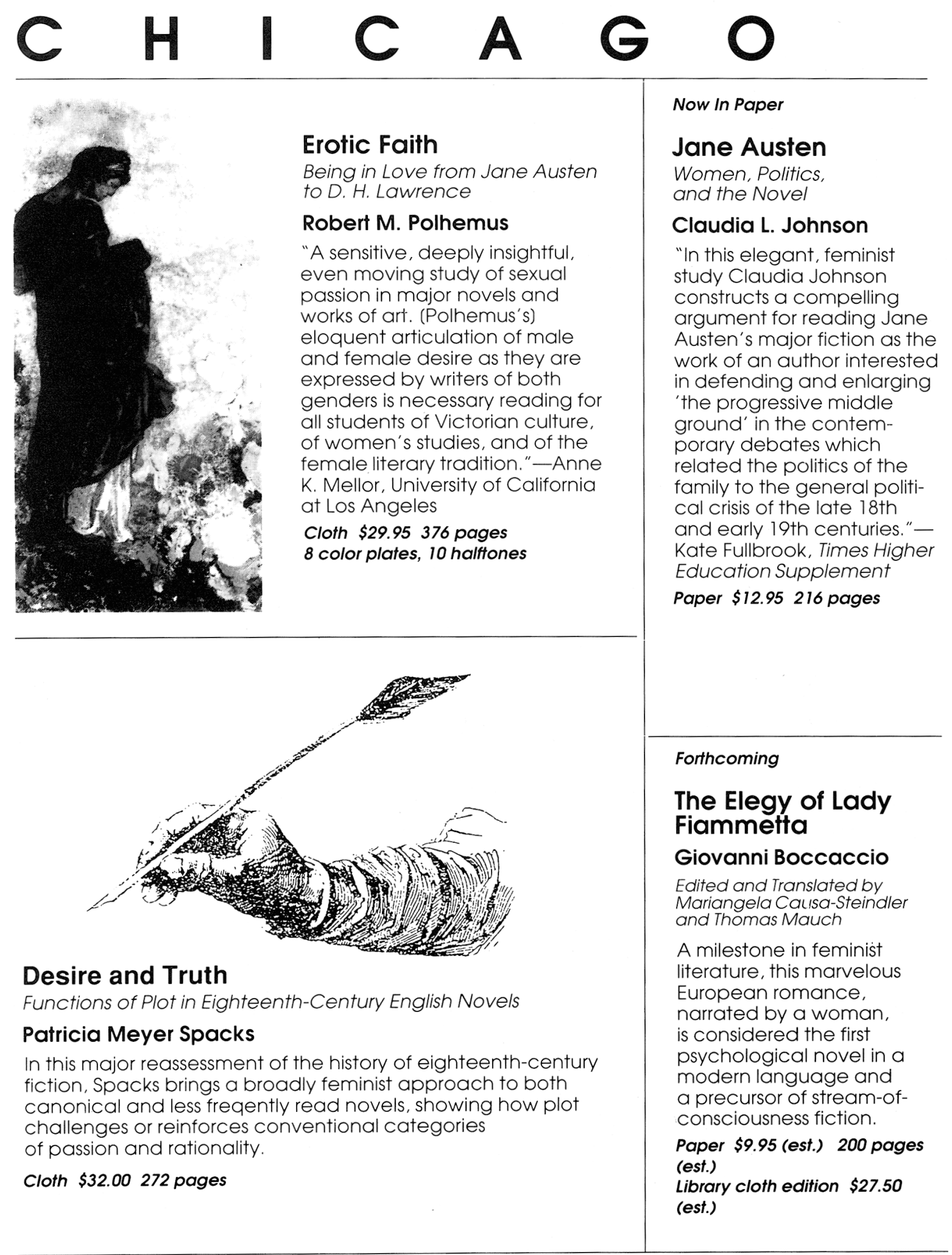

\title{
THE UNIVERSITY OF CHICAGO PRESS
}

\author{
5801 SOUTH ELLIS AVENUE CHICAGO, IL 60637
}

At bookstores, or call: 1-800-621-2736. In Illinois: 312-568-1550 


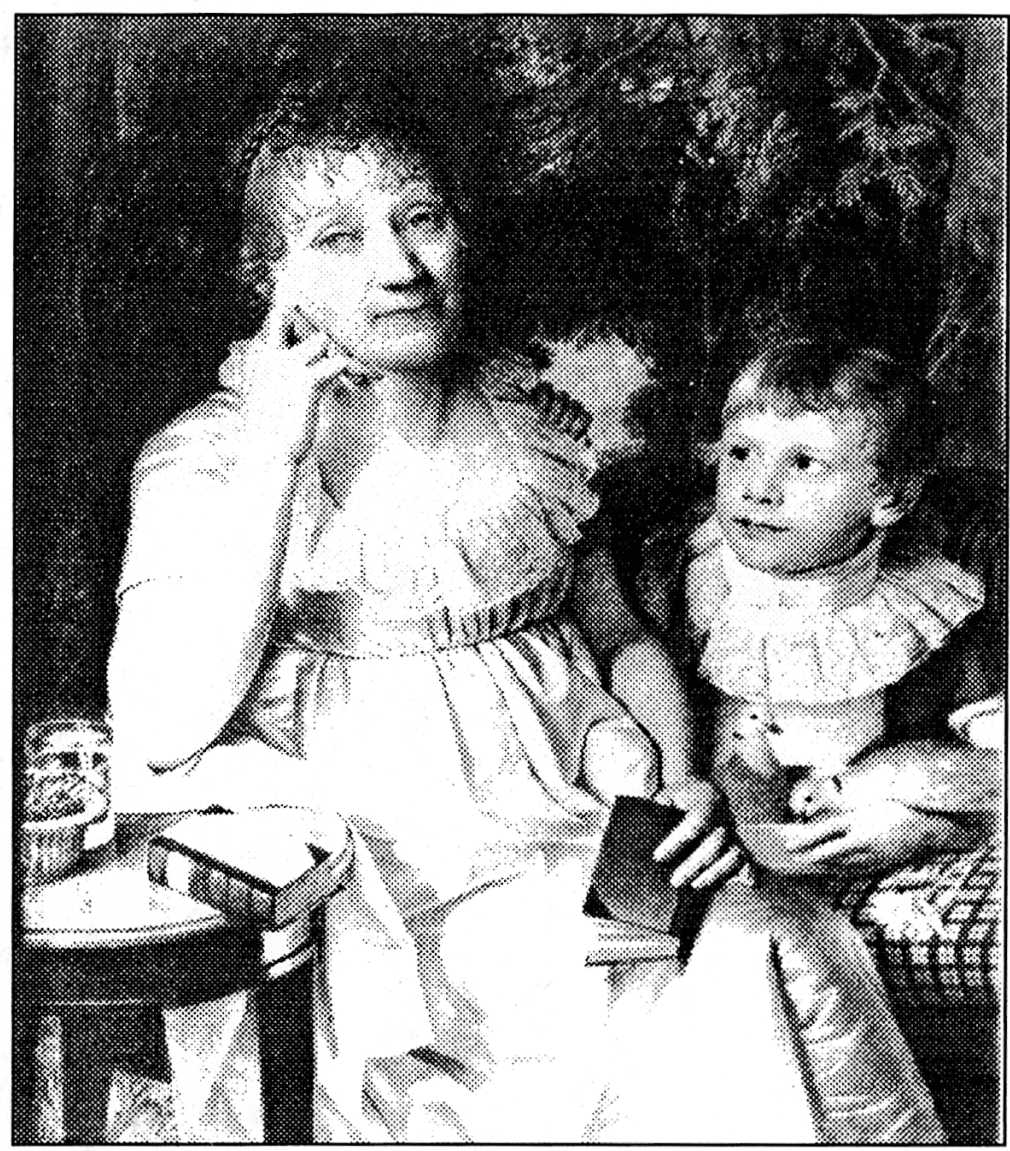

\section{Autobiographical Tightropes}

Simone de Beauvoir, Nathalie Sarraute, Marguerite Duras, Monique Wittig, and Maryse Condé

By Leah D. Hewitt

These five French women writers of the second half of the twentieth century illustrate that producing autobiography is like performing a tightrope act on the slippery line between fact and fiction. Autobiographical Tightropes emphasizes the tension in the works of these major writers as they move in and out of "experience" and "literature," violating the neat boundaries between genres and confusing the distinctions between remembering and creating. $\$ 25.00$

\section{Bitter Healing}

German Women Writers

from 1700

to 1830

An Anthology

By Jeannine Blackwell and

Susanne Zantop

Bitter Healing is the first anthology of eighteenth- and early nineteenth-century German women's writing in English translation. It goes far toward filling a major gap in literary history by recovering for a wide audience the works of women who were as famous during their lifetimes as Wieland, Schiller, and Goethe. A volume in our series, European Women Writers. $\$ 38.50$ cl, \$14.95 pa

\section{Winged Words}

American Indian Writers Speak

By Laura Coltelli

Some of the most highly regarded contemporary Indian poets and novelists appear together for the first time to discuss major issues confronting current Indian writers. Paula Gunn Allen, Michael Dorris, Louise Erdrich, Joy Harjo, Linda Hogan, N. Scott Momaday, Simon Ortiz, Wendy Rose, Leslie Marmon Silko, Gerald Vizenor, and James Welch are the writers interviewed. A volume in our series, American Indian Lives. $\$ 22.50$

\section{University of Nebraska Press • 901 N $17 \cdot$ Lincoln $68588 \cdot 0520$}

